independent professional activity and by his/her readiness to navigate quickly in the modern multidisciplinary space. An interprofessional approach to the activities of physical therapists and occupational therapists, enabling them to bring together unique qualifications to create an effective team that integrates the knowledge and skills of different health disciplines, combined with the ability to work as a holistic system. Effective interprofessional collaboration practices provide appropriate assistance to patients, their families, careers, society, and improve the outcomes of physiotherapy interventions, along with the services of related fields. The interprofessional practice of collaboration gives patients a reduction in the number of complications, the frequency and duration of hospitalizations, the number of clinical errors, mortality rates, tensions, and conflicts among healthcare professionals. In our opinion, the quality of professional activity of physical therapists depends both on the competence of the individual specialist and on his/her readiness for interprofessional interaction. According to the results of the study of methods of organization of interprofessional education of specialists in physical therapy and ergotherapy, the following forms of inclusion of interprofessional training in the educational process can be distinguished: distance learning, interprofessional courses, teamoriented training, clinical-based training, problem-oriented training technology, simulation training, clinical practice, student clinics, project-oriented training. Based on the analysis of scientific and methodological literature, it is proved that the listed methods of organization of interprofessional education of specialists in physical therapy and ergotherapy are acceptable and necessary for distribution in the educational field "Physical therapy and ergotherapy". We consider the issues of development of methodology and pedagogical approaches to the practical application of the proposed pedagogical technologies in the organization of interprofessional education of specialists in physical therapy and ergotherapy promising for further research.

Key words physical therapy, ergotherapy, vocational training, interprofessional education, distance learning, interprofessional courses, command-oriented training, clinicalbased training, problem-oriented training, simulation training, clinical practice, student clinics, project-oriented training.

UDC 378.147:37.091.113]:[001.895:008]:378.22

\author{
Dmytro Kozlov \\ Sumy State Pedagogical University \\ named after A. S. Makarenko \\ ORCID ID 0000-0003-1875-0726
}

DOI 10.24139/2312-5993/2019.07/206-214

\title{
MODERN TECHNOLOGIES IN THE DEVELOPMENT OF INNOVATIVE CULTURE OF THE FUTURE MANAGER OF THE EDUCATION INSTITUTION IN THE MASTER'S TRAINING PROCESS
}

A number of new communication technologies have emerged in recent years that are largely regarded and intended for personal and recreational use. However, these "conversational technologies" and "constructivist learning tools" coupled with the power and reach of the Internet, have made them viable choices for both educational and knowledgeoriented applications. The technologies which are considered in this article include instant messaging (IM), Weblogs (blogs), wikis, podcasts, etc. Technologies, underlying educational and cognitive psychology theories, and also applications for education of future managers of the education institution are examined in detail. 
Key words modern technologies, instant messaging (IM), Weblogs (blogs), wikis, podcasts, innovative culture, formation of innovative culture, future manager of the education institution, master's training process.

Introduction. Nowadays development of the theory and methodology of teaching future managers of the education institution is aimed at achieving definite studying results among which gaining an innovative culture is considered to be the most relevant. The growing importance of formation of innovative culture of future managers of the education institution across the world in recent years can be partly explained by shifting the focus from grammaticality and form compliance into meaning and function loyalty.

Thus, it is highly important for higher pedagogical institutions to take on the vital role of the development of the modern society by designing curriculum of master's training process for future managers of the education institution to develop innovative culture.

The objective of this work is to incorporate technology into teaching methods to create rich learning experience for students and a rewarding teaching experience for faculty. Two educational models practiced across the globe are face to face learning and hybrid learning. This traditional method of teaching and learning is synchronous and typically involves employment of a classroom environment where professor and students interact within time and space. This model of teaching is called synchronous. Interactions with face to face and distance learning techniques disseminate information to members of a learning community. This type of learning blends technology based asynchronous teaching method and traditional teaching method that are often under review by a lot of researchers.

Consequently, there is a need for a comprehensive research analysis of the modern technologies in the context of the innovative culture development of the future manager of the education institution in the master's training process.

Analysis of relevant research. There have been numerous studies conducted, and papers written, about the use of technology in the classroom, together with work on the related areas of e-learning, Web-based learning, and online learning. The usage of computing technologies in education has been examined in numerous studies, and there is a sizable body of work on Web and online learning, including the studies by Ahn, Han, and Han (2005), Liu and Chen (2005), Beck, Kung, Park, and Yang (2004), and numerous others.

In particular, some of these technologies have been recognized as useful in the classroom, and have been applied in innovative ways. Of particular interest are technologies that are referred to as "conversational technologies", which allow creation and sharing of information (KPM G, 2003; Wagner, 2004).

Another term that are often used to describe these technologies is the concept of "constructivist learning tools", which encourage, and are focused on users creating, or constructing, their own content (Seitzinger, 2006). 
In the management literature, culture has been identified as one of the main determinants for success in organizational transformation, which further stresses the importance of understanding innovation culture properly.

Recently, scholars have argued that the capabilities can be applied to innovation and an increasing number of large firms set their focus on developing a capability to being innovative (Börjesson, Elmquist, \& Hooge, 2014; O'Connor, Paulson, \& DeMartino, 2008). It has been argued that an innovation in firm's capabilities are important both for its competitiveness (Björkdahl \& Börjesson, 2012), and its growth (O'Connor, 2008).

Thus, the issues of the modern technologies in the context of the innovative culture development of the future manager of the education institution in the master's training process are becoming relevant nowadays.

The aim of the article - to conduct a comprehensive research analysis of the modern technologies in the context of the innovative culture development of the future manager of the education institution in the master's training process.

Research Methods: Solving the highlighted aim, a set of methods of scientific research adequate to them were used, theoretical: a comparative analysis of the scientific definitions of modern technologies, a systematic analysis of modern technologies as an integrative personality quality of the future manager of the education institution; empirical: analysis of various modern technologies of the future manager of the education institution; analysis of the modern technologies of the future manager of the education institution in the magister training process.

Results. The notion of technologies is not a new one, as it encompasses many types of systems that have been widely used for some time, including email, video conferencing, and discussion forums. The term "conversational technology" is derived from the work of Locke et al. (2000) relating to conversational exchanges and his Cluetrain Manifesto. One of the key concepts here is that "markets are conversations" and that knowledge is created and shared using question and answering dialog. Specific theses that relate to this form of "conversational knowledge management" suggest that aggregation and abstraction of information helps to create information. Other characteristics of conversational knowledge management include the fact that it is fast, stored in different locations, and does not require sophisticated technologies in order to be accomplished (Wagner, 2004). Conversational technologies encompass a wide range of systems and software, many of which are familiar, including e-mail, instant messaging, Web pages, discussion forums, video and audio content/streaming, wikis, and Weblogs. While there are specific aspects that are of interest in terms of the more mature technologies, the ones that will be given attention in this article are the issues, impacts, and applications relating to IM, blogs, wikis, and podcasts. These are technologies that are newer, have a growing base of users, and are starting to become recognized as viable tools for education. 
It is unlikely that there would be many college students who are unfamiliar with the use of IM. Allowing for interactive and real-time synchronous communications with instant response, instant messenger is truly conversational in that it allows for "chat" and communications between both individuals and groups. The major instant messaging systems in use include AOL (AIM), MSN Messenger, Yahoo! Messenger, and ICQ. IM is a means for users to "chat" and communicate in real-time. While originally the domain of personal users, over time the unique benefits and effectiveness of this medium were realized, and IM started to become accepted as a form of communication in businesses (particularly high-tech firms), and now has been studied and tested as an educational tool (Kinzie, Whitaker, \& Hofer, 2005). The important features of IM include both its synchronous nature and its ability to support both chat and phone-like interaction. While real-time interaction allows for rapid communications to occur, there is also no need to enter an interaction "space" as with chat rooms. Instead, the main usage of IM is in one-on-one communications, which can be more formally termed as a dyadic "call" model, which more closely resembles phone call interaction. It should be noted that even though much of the communication is done between two individuals, there are some systems that support multiparty instant messaging.

An important difference between IM and e-mail is the tendency for instant messenger interaction to be more casual and informal than e-mails, which helps to bring about a more "friendly" communication atmosphere. This may in part be due to a reduction in the formalities that are typically involved when using e-mail or phone. In particular, IM has been considered more suitable for such tasks as scheduling meetings, asking or answering quick questions, and for other kinds of tasks that are brief, require a prompt response, or are less formal. It is perceived to be far simpler to IM someone to ask a quick question, for example, or to confirm a meeting or lunch, rather than to e-mail or call (Nardi \& Bradner, 2000).

Blogs started as a means for expressive individuals to post online diaries of themselves. Complete with text and photos, these logs were essentially an individual's online narrative or diary, with events, stories, and opinions. While its original use was for personal expression, recently its effectiveness as a tool for education has been discovered, including its use as an extension of "learning logs", which are created online (Barger, 1997). One of the earliest blogs, as we know and use them today, was Dave Winer's Scripting News, which was put online in 1997. While the use of Weblogs can be considered generally new, the concepts of keeping a "log" or "learning log" is not. The concept of "learning logs" has been in use since before the advent of the Weblog. The concept of this is to enable someone to document his or her learning, and also to do some critical reflection (Fulwiler, 1987) and selfanalysis. The use of a learning log or journal is related to action research 
learning strategies (Cherry, 1998) and attempts to link previous knowledge and new information learned. Blogs are a natural extension of learning logs/journals in that they are electronic and can be made available ("published") more easily (Armstrong, Berry, \& Lamshed, 2004). The use of electronic Weblogs as educational tools offers the benefits of increased information sharing, simplified publication of information, and improved instructor monitoring and review (Flatley, 2005; Wagner, 2003). The use of blogs has been expanding, as Perseus Development reported that there were some 10 million blogs in 2004, and the number is ever increasing (Nussbaum, 2004). The growth in this area is expected to increase in the years to come.

However modern technologies engage students with different kinds of stimuli involve in activity based learning. Technology makes material more interesting. It makes students and teachers more media literate. Technology is a means to justify the end of composition outcomes and has become a seamless extension of the curriculum in the magister training process. Technological Pedagogical Content Knowledge captures the qualities of this new hybrid educator who must find his or her place between the intersections of these qualities. To most effectively teach technology, we must model that technology within our disciplines and classes.

Voice Thread is a web service that allows users to upload PowerPoint slides, videos, photos, et al. and add voice narration to create a multimedia presentation and use it in the master's training process. Voice Thread is an application that runs inside your web browser and it allows you to transform collections of media, like images, videos, documents, and presentations, into a place for a conversation. These conversations are not live, but take place whenever it's convenient for the people to participate. They are also secure, with simple controls that let you dictate who can participate and what they can do.

Educators use Voice Thread for many different reasons, from extending and documenting classroom conversations, online tutoring, virtual class spaces, professional development training, and a thousand things in between. The advantages of the voice thread are as follows. It starts students-the future managers of the education institution driven discussions with better understanding. It is a great way to deliver projects and solicit feedback. The information about voice threads is available on the following links.

Blogging is a public post. Blogging for study sessions is to be practiced. Students can post case studies in a class blog. Students-the future managers of the education institution can be asked to post notes on class blog within the master's training process. You can analyze, evaluate and create the material. Blogging causes you to reflect. Teachers naturally think back on what has happened in the master's training process, and often wonder what they could have done better. Blogging can help with this process, enabling teachers to keep an ongoing personal record of their actions, decisions, though processes, 
successes and failures, and issues they have to deal with. Blogging can crystallize your thinking. As we write, we invest a part of ourselves into the medium. The provisionally of the medium makes blogging conducive to drafting and redrafting. The act of composing and recomposing ideas can enable abstract thoughts to become more concrete. Your ideas are now on the screen in front of you; they can be stored, retrieved and reconstructed as your ideas become clearer. You don't have to publish if you want to keep those thoughts private. Save them and come back to them later. The blog can act as a kind of mirror to show you what you are thinking. Sometimes we don't really know what we are thinking until we actually write it down in a physical format.

Prezi-Your Presentations is a new way to do the presentations in the master's training process of the future manager of the education institution. Prezi is a versatile app that lets you make professional-looking presentations. It's like a free, pared-down version of PowerPoint. Prezi lets you make presentations that are as casual or as professional as you want them to be. It allows you to add information to a prezi, organize it in a logical way, embellish it with audio and video and then share it with the people you need to reach. Prezi makes making a presentation very easy. The whole app flows very easily even without looking at the intro or help; you can dive into a new presentation competently. It is worth looking at the help and online resources to get the most out of it, but even taking Prezi in isolation, it's very usable. Before Prezi, there was PowerPoint, and to a large extent, that was it. PowerPoint is a great piece of software, don't get us wrong, but there was definitely room for a change. Prezi feels fresh and easy, but still produces nice looking presentations. It's also capable of dealing with feature rich and complex material and making it look good.

Another modern technology is Social Bookmarking. Bookmarking is the simple process of saving the address of a website in the favorite folder of your web browser so that you can find it again later. Social bookmarking takes these process two steps further. Firstly, instead of saving the bookmarks to your favorite folder, it saves them online. The great advantage of this is that you can then access them from any computer, not just the one you saved them on, simply by logging into your social bookmarking account. This enables you to access your favorite sites from wherever you are, rather than wherever you bookmarked the site. The second advantage is the social part. Saving bookmarks online enables you to easily share them with other internet users and for you to access their bookmarks as well. This can help you find and access many more useful websites; especially as many social bookmarking sites enable you to join special interest groups and finds people who have similar interests to you. The benefits of social bookmarking are that it is easy to share and manage social bookmarks. Searching and storing in database is also easy.

Podcasts, in the master's training process of the future manager of the education institution in the context of the innovative culture development, are 
serial recordings, posted regularly online. Basically, producing podcasts is the technology based equivalent of oral lectures. Much as lectures and news have been shared with listeners, who download the files online. The advantages of podcast are its flexibility, reusability of your lecture. It is advantage for students with hearing impairements.

Screencasts have emerged as a prominent teaching tool on the Internet in the master's training process of the future manager of the education institution in the context of the innovative culture development. Screencasts are an effective way to share ideas, deliver content, and obtain student feedback. Screencasts can be used for describing a step-by-step process, explaining a particular concept, or making a PowerPoint presentation with narration and multimedia elements. A screencast can be used in any class as a part of real time instruction or as the lesson itself as in the flipped teaching model. With the flipped teaching method, instructors use screencast videos to deliver their lectures, assigning them as homework. Then, in class, students can ask questions as they work through problems that they normally would have done at home without teacher help. Creating an educational screencast that meets content objectives requires a systematic approach to planning. It seems clear that screen casting is a powerful, highly effective, and affordable learning tool that can facilitate learning across any curriculum area. Screen casting is a remarkable instructional tool. These are the free software's available for instructors which teach and saves time. Jing, Screen jelly, screen, Screencast are some of the freebies available.

Conclusions. In conclusion, it should be stressed that preparation of the future manager of the education institution for lifelong learning should begin in the context of the master's training process, providing, based on the analysis of domestic and foreign experience, the use of adult education in the master's training process as a pre-emptive factor that will encourage the future manager to continue education.

Any teaching method without destroying the objective could be considered as innovative teaching methods in the master's training process. The researchers believe that the core teaching objective is passing on the information or knowledge to the students' minds. There is a number of ways that teachers can bypass the system and offer students the tools and experiences in the context of the innovative culture development.

Perspectives of the further research. The further research requiers the issue of using the latest teaching forms in the master's training process for the future managers of the education institution in the context of the innovative culture development.

\section{REFERENCES}

Armstrong, L., Berry, M., \& Lamshed, R. (2004). Blogs as electronic learning journals. EJournal of Instructional Science and Technology, 7 (1). Retrieved from http://www.usq.edu.au/ electpub/e-jist/docs/Vol7_No1/CurrentPractice/Blogs.htm. 
Barger, J. (1997). Weblog resources FAQ, Robot Wisdom Werblog. Retrieved from: http://www. robotwisdom.com/weblogs.

Björkdahl, J., \& Börjesson, S. (2012). Assessing firm capabilities for innovation. International Journal of Knowledge Management Studies, 5 (1), 171-184.

Bonk, C. J. (1998). Recommendations for placing the student at the center of web-based learning. Educational M edia International, Vol. 35, no. 2, 82- 89.

Cherry, N. (1998). Action research: A pathway to action, knowledge, and learning. RMIT Publishing.

Developing and Validating a Measure of Web Personalization Strategy Haiyan Fan and Liqiong Deng (2008). International Journal of Technology and Human Interaction, 128. Retrieved from: www.igi-global.com/article/developing-validating-measurewebpersonalization/2929? camid=4v1a.

Flatley, M. (2005). Blogging for enhanced teaching and learning. Business Communication Quarterly, 68.

Fulwiler, T. (1987). The journal book. Portsmouth, NH: Boynton/Cook.

Gunn, E. (2014). Using clickers to collect formative feedback on teaching: a tool for faculty development. International Journal for the Scholarship of Teaching and Learning, Vol. 8, no. 1 , article 11 .

Khairnar, C. M. (2015). Advance Pedagogy: Innovative Methods of Teaching and Learning. International J ournal of Information and Education Technology, Vol. 5, No. 11, 869-872.

King, S. B. (2014). Graduate student perceptions of the use of online course tools to support engagement. International Journal for the Scholarship of Teaching and Learning, Vol. 8, no. 1, 130-132.

Kinzie, M., Whitaker, S., \& Hofer, M. (2005). Instructional uses of instant messaging during classroom lectures. Educational Technology and Society, 8 (2), 150-160.

Locke, C. et al. (2000). The Cluetrain Mainfesto: The end of business as usual. Cambridge, MA: Perseus.

M obile Learning John M. Traxler and Helen Crompton (2015). Encyclopedia of M obile Phone Behavior, (pp. 506-518). Retrieved from: www.igi-global.com/chapter/mobilelearning/ 130168 ?camid=4v1a.

Nardi, B., \& Bradner, E. (2000). Interaction and outeraction. In Proceedings of CSCW'00. Philadelphia, PA.

Nussbaum, E. (2004, January 11). M y so-called blog. The New York Times.

O'Connor, G. C., Paulson, A. S., \& DeMartino, R. (2008). Organisational approaches to building a radical innovation dynamic capability. International Journal of Technology Management, 44 (1), 179-204.

Several Simple Shared Stable Decision Premises for Technochange Richard Diamond (2007). International Journal of Technology and Human Interaction, (pp. 66-75). Retrieved from: www.igi-global.com/article/several-simple-shared-stabledecision/2913? camid=4v1a.

Visualizing ICT Change in the Academy G. Parchoma (2007). Enhancing Learning Through Human Computer Interaction, (pp. 1-20). Retrieved from: www.igiglobal.com/chapter/visualizing-ict-change-academy/ 18332? camid=4v1a.

Wagner, C. (2004). Wiki: A technology for conversational knowledge management and group collaboration. Communications of the AIS, 13 265-289. 


\section{АНОТАЦІЯ}

Козлов Дмитро. Сучасні технології розвитку інноваційної культури майбутнього керівника закладу освіти в процесі магістерської підготовки.

Останніми роками з'явилася низка новітніх технологій, які розглянуто та призначено для особистого і рекреаційного використання майбутніми керівниками закладу освіти у процесі магістерської підготовки в контексті розвитку інноваційної культури. Зазначено, що технології, яким приділено увагу в статmі, включають миттєві повідомлення (чат), веб-журнали (блоги), вікі-сайти та подкасти та інші. Детально розглянуто означені сучасні технології та їх упровадження у прочес магістерської підготовки майбутніх керівників закладу освіти.

Ключові слова: сучасні технології, обмін миттєвими повідомленнями (IM), веб-журнали (блоги), вікі, подкасти, інноваційна культура, формування інноваційної культури, майбутній керівник закладу освіти.

\section{PEЗЮME}

Козлов Дмитрий. Современные технологии развития инновационной культуры будущего руководителя учебного заведения в процессе магистерской подготовки.

В последние годы появился ряд новейших технологий, которые рассмотрены и предназначены для личного и рекреационного использования будущими руководителями учебного заведения в процессе магистерской подготовки в контексте развития инновационной культуры. Отмечено, что технологии, которым уделено внимание в статье, включают мгновенные сообщения (чаты), веб-журналы (блоги), вики-сайты и подкасты и другие. Детально рассмотрены указанные современные технологии и их внедрение в процесс магистерской подготовки будущих руководителей учебного заведения.

Ключевые слова: современные технологии, обмен мгновенными сообщениями (ИМ), веб-журналы (блоги), вики, подкасты, инновационная культура, формирование инновационной культуры, будущий руководитель учебного заведения.

$$
\text { удк 371.315.6:51 }
$$

\section{Ольга Косович}

Тернопільський національний педагогічний університет імені В. Гнатюка ORCID ID 0000-0002-1651-9769 DOI 10.24139/2312-5993/2019.07/214-224

\section{КЛАСИФІКАЦІЯ І КРИТЕРІЇ ВІДБОРУ НАВЧАЛЬНОГО МАТЕРІАЛУ ДЛЯ ФОРМУВАННЯ АНГЛОМОВНОЇ АУДИТИВНОЇ КОМПЕТЕНТНОСТІ СТУДЕНТІВ}

У статті зазначається, що аудіювання - це складний активний процес мовленнєво-розумової діяльності, що вимагає детального вивчення як із точки зору функціонування механізмів сприйняття, так і розвитку аудитивних умінь і навичок. Автором розглядаються основні критерії відбору звукового матеріалу в прочесі аудіювання, зазначаються основні характеристики, які необхідно враховувати при розробленні завдань для навчання аудіювання студентів, які вивчають англійську мову як другу іноземну. Автор підкреслює, що автентичні тексти дочільно використовувати на всіх етапах навчання аудіювання, ураховуючи рівень володіння мовою студентів і тривалість звучання тексту. 